\title{
Determinants of public funding for innovation in Chilean firms
}

\author{
Determinantes del financiamiento público para la innovación en \\ empresas chilenas
}

\author{
Cristian Mardones* and Annabella Zapata
}

Universidad de Concepción, Chile

Received 26 July 2017; Accepted 03 September 2018

Available online 10 November 2018

\begin{abstract}
In this study, different versions of the Innovation Surveys carried out in Chile are used to evaluate the factors that would explain the obtaining of public funding for innovative activities. In order to achieve this, the estimated results from binary election models are contrasted with cross-sectional and pseudo-panel data. It is concluded that with pseudo-panel data it is possible to identify some relevant factors not observed with cross-sectional data, for example those firms that invest in training their workers in $\mathrm{R} \& \mathrm{D}$ activities in the previous year have lower probabilities of obtaining public funding. In addition, the foreign firms have greater probabilities of achieving funding than national firms. The most striking result is that larger firms have greater probability of obtaining public funding, which is contradictory when considering that many public programs declare that they are aimed to support SMEs.
\end{abstract}

JEL Codes: C23; $\mathrm{O} 3$

Keywords: Pseudo-panel; Probit; Public funding.

*Corresponding author.

E-mail address: crismardones@udec.cl (C. Mardones)

Peer Review under the responsibility of Universidad Nacional Autónoma de México.

http://dx.doi.org/10.22201/fca.24488410e.2018.1602

0186-1042/C 2019 Universidad Nacional Autónoma de México, Facultad de Contaduría y Administración. This is an open access article under the CC BY-NC-SA (https://creativecommons.org/licenses/by-nc-sa/4.0/) 


\section{Resumen}

En este estudio se utilizan diferentes versiones de las Encuestas de Innovación en Empresas realizadas en Chile para evaluar los factores que podrían explicar la obtención de financiamiento público para actividades innovativas. Para ello, se contrastan los resultados estimados a partir de modelos de elección binaria con datos de corte transversal y pseudo-panel. Se concluye que con los datos de pseudo-panel es posible identificar algunos factores relevantes que no se observan cuando se utilizan datos de corte transversal, por ejemplo que aquellas firmas que invierten en capacitar a sus trabajadores en actividades de I\&D en el año anterior tienen menor probabilidad de obtener financiamiento público, y además, que las firmas extranjeras tienen mayor probabilidad de conseguir el financiamiento que las firmas nacionales. El resultado más llamativo es que mientras más grande sea la firma tiene mayor probabilidad de obtener financiamiento, lo cual es contradictorio considerando que muchos de los programas públicos declaran que tienen por objetivo apoyar a las PYME's.

Códigos JEL: $\mathrm{C} 23, \mathrm{O} 3$

Palabras clave: Pseudo-panel; Probit; Financiamiento público

\section{Introduction}

Generally, public funds for $\mathrm{R} \& \mathrm{D}$ are associated to tax benefits that involve automatic procedures or subsidies obtained through competitive funds that are based on an evaluation of proposal formulated by the applicant firms. In the case of subsidies, their main disadvantage is that they may involve discretionary decisions in the selection of projects (Bozeman \& Link, 1984), though subsidies are more useful for funding projects with a major gap between social and private return, as well as to support potential complementarities between innovative activities (Mohnen \& Röller, 2005).

In developed countries, government funding for R\&D activities has become an important tool of the innovation policy (Clausen, 2009; Cappelen et al., 2012; Bronzini \& Piselli, 2016), since the uncertain returns of the investment in $\mathrm{R} \& \mathrm{D}$ added to the information asymmetries with external investors affects the conditions to finance this type of projects. However, public funds are subjected to selection by state agencies and there is self-selection by firms, because those that apply or receive funding are not considered as representative of the population of firms (Cerulli, 2010).

In Chile, R\&D expenditure as a percentage of the Gross Domestic Product (GDP) was $0.4 \%$, which is low compared to other Latin American countries such as Argentina (0.6\%) and Brazil (1.2\%). In addition, this gap is even higher when compared with the average R\&D expenditure of the OECD member countries (2.4\%). Therefore, in recent years the Chilean State has had a more active role through the creation of diverse programs and incentives that promote innovative projects and strengthen the entrepreneurial capacities. However, despite the diversity of programs and incentives, there is little information to measure their effectiveness. For instance, in the different versions of the Innovation Survey only the well-known support 
programs such as CORFO ${ }^{1}, \mathrm{FIA}^{2}$, INNOVA CHILE ${ }^{3}$, INNOVA Bío Bío ${ }^{4}$ and FONDEF FNave $^{5}$, been consulted. In addition, only in some versions of this survey is disaggregated by type of program, which hinders its evaluation at individual scale.

Previous literature has determined that some characteristics of the firms such as the belonging to a group, export experience, financial structure, innovation, and R\&D efforts carried out in previous years are related to the public funding for R\&D. For instance, Antonelli \& Crespi (2013) when analyzing the factors that affect the probability of achieving public funding for R\&D suggest that having obtained this type of resource in the past increase the possibility of achieving additional funding. Thus, they conclude that subsidies in R\&D have a persistent nature and that the stable pattern of access to this type of funds is associated with a strategy of choosing the winners by the government. Duguet (2003) concludes that the probability of obtaining a subsidy increases with the size of the firm, the ratio of private investment in $R \& D$ respect to sales, the debt ratio, the existence and magnitude of a past public support and in addition, it varies with the line of business. Afcha (2012) determines that the cooperation networks, recruitment of recently graduated professionals, $R \& D$ expenditures of previous years, number of employees, and mount of exports have a positive influence on the probability of obtaining a subsidy for R\&D. Dush et al. (2011) point out that having previous experience in R\&D projects positively affects the intensity of the subsidies, that the consolidated firms have greater responsibility of obtaining such support, that the expenditure in R\&D activities and the participation in previous calls for public funds are also factors that increase the probability of being beneficiaries. In addition, the agency in charge of granting the support prefers to benefit firms that acquire external research. Hussinger (2008) estimates the probability of receiving public funding for R\&D in Germany, concluding that the government chooses to finance the most promising candidates, which are characterized by having obtained financing in the past, having larger size, financial solvency and patenting activities in the past. Almus \& Carnitzki (2003) show that obtaining public funds depend on the industrial sector, firm size, presence abroad, market and the existence of a R\&D department. Busom (2000) concludes that subsidies tend to favor smaller firms and those that have no foreign capitals, which can be associated to government decisions, because these types of firms have greater restrictions on credit. Takalo $e t$ al. (2008) argue that the most challenging projects have more probabilities of being subsidized, that the market risk decreases this probability, and that small and medium firms obtain higher subsidies than larger firms. In addition, they point out that the number of previous requests has no effect on the granting of support. Gongora-Bianchi et al. (2009) indicate the Mexican firms that request public funding have greater technological level, whereas the firms selected to receive funding are more oriented to international markets, have an exploratory-analytical strategy and exhibit high technology. Finally, Huergo et al. (2016) show that the firms that

\footnotetext{
${ }^{1}$ It is intended to promote research and technological development with economic impact, promote business associativity, modernize the management of firms, promote access to financing and stimulate private investment.

${ }^{2}$ Its strategic lines support innovative processes that add value to the agricultural sector.

${ }^{3}$ It seeks to strengthen the access of micro, small and medium firms to networks and business alliances to improve their competitiveness, promote and support the early stages of the development of innovations and entrepreneurships, and also support technology transfer, incorporation of R\&D and the generation of infrastructure that facilitates innovation.

${ }^{4}$ Its mission is to consolidate the Biobío Region by promoting innovation, knowledge transfer and technological capabilities.

${ }^{5}$ Its lines of action seek to support projects of applied R\&D that are oriented to generate economic and/or social changes, as well as support the generation of entrepreneur skills based on innovative research carried out by students graduated from Chilean universities.
} 
belong to the high-tech sector, have performed expenses in $\mathrm{R} \& \mathrm{D}$ in the previous year and have received some type of assistance previously have greater probabilities of obtaining this funding.

Other studies have been focused on the behavior of agencies that allocate funding for R\&D. For example, Blanes \& Busom (2004) investigate different programs of R\&D in Spain, concluding that the firms of the same industrial sector may face diverse obstacles to participate in programs of different agencies, that the patterns of participation may reflect a combination of objectives of the agency, and also that the patterns differ between low and high technology sectors. Cantner \& Kösters (2012) investigate the allocation of public funds to start-ups in Germany and their effect within the first years, affirming that policymakers and members of evaluating committees follow a strategy of "picking the winner", and in addition, that the work team of the start-up and the initial capital of the firm tend to positively affect the obtaining of these funds. Colombo et al. (2011) study the effectiveness of the public support for R\&D in high-tech Italian firms and find that the subsidies granted selectively and over a competitive base have a positive and significant effect on the firms benefited, whereas those subsidies allocated through an automatic process have no such effect.

In order to analyze the allocation of public funding, the probit method is commonly used. For instance, with this method Hussinger (2008) estimates the probability of perceiving public funding for R\&D in Germany, whereas Herrera \& Sánchez (2012) analyze the variables that affect the allocation of public funding in Spain. However, the statistical methodologies used can be diverse and depend on the type of data available. For example, Boeing (2006) investigates the allocation of subsidies in $\mathrm{R} \& \mathrm{D}$ in China with different evaluation methods such as propensity score matching, differences in differences and instrumental variables. Blanes \& Busom (2004) investigate the probability of participation in R\&D through a multinomial logit method. Corchuelo \& Martínez-Ros (2010) investigate the effect of tax incentives by using the matching and heckit methods.

Regarding the determinants of the private investment in $R \& D$, the study carried out by Crespi \& Zuñiga (2012) can be mentioned. These authors when analyzing data from six Latin American countries (including Chile) conclude that the firms that invest more in knowledge tend to introduce new technological advances and those firms that innovate more have higher labor productivity. In addition, these authors determine that the firms characterized by performing cooperative activities, having foreign ownership and export experience have greater probability to invest in private funds in $\mathrm{R} \& \mathrm{D}$, whereas the sources of market or scientific information have little or null impact on the innovative efforts of the firms. This is explained because in many Latin American countries the innovations of the firms consist in small changes based on imitation or technological transfer that practically have no international impact (Navarro et al., 2010).

It should be noted that the previous studies carried out in Chile have focused mainly on the relation between productivity of the firms and innovative variables (Benavente, 2005; Benavente, 2006; Álvarez et al., 2011; Álvarez et al., 2015), but they have not analyzed which factors influence the probability of obtaining public funding. Specifically, Benavente (2006) states that the innovative activities are positively associated with firm size and market power and additionally, the short-term productivity is not affected the expenditure in R\&D. On the other hand, Álvarez et al. (2015) point out that the determinants of technological and nontechnological innovation in the manufacturing and service sectors are very similar. Therefore, this study is aimed to evaluate whether the characteristics of the firms have an impact on the probability of obtaining public funding for $\mathrm{R} \& \mathrm{D}$ in Chile. In addition, the impact of these 
factors is contrasted when cross-sectional data of the Innovation Survey are analyzed respect to pseudo-panel data that are constructed from cross-sectional data from the 5th to the 9th Innovation Survey.

Consequently, the aim is to evaluate whether firms that have developed innovative activities in the past have greater probability of obtaining public funding for $R \& D$, because from the point of view of the state agency, the accumulated knowledge and experience would allow them to have a great probability of success, although this could turn into something negative for the new firms that present good projects but without having innovative experience. It is also intended to test if the case of Chile confirms that some characteristics of firms previously described in the empirical literature and that are observable for the state agency in the period of application condition the obtaining of funding. According to the literature and available variables the specific hypothesis to test are the following: observable characteristics in the previous year such as expenditure on equipment for innovation, expenditure on external knowledge, expenditure in training, expenditure on introducing innovation to market, expenditure in other innovation activities, number of intellectual property requested by the firm, total sales, number of workers, export experience, economic sector, geographic location, firm size (large, medium and small, taking microenterprises as base) and type of ownership (private, foreign or mixed, taking state firms as base) affect the probability of obtaining public funding for R\&D. If these hypotheses are rejected, it could be affirmed that the state agency determined the winners based only on the merits of the proposals presented and not on the characteristics of the applicant firms. Otherwise, results of this study are important for the firms because they could alter their decisions and/or characteristics before applying to this type of funds in order to increase their chances of awarding.

\section{Methodology}

\section{Available data}

The Innovation Survey measures different types of indicators and variables performed by Chilean firms located in different regions of the country and that belong to different economic sectors. The design of the form and the methodology for gathering information in its more recent versions follow the general guidelines suggested by OECD and the Eurostat Community Innovation Survey for this type of surveys. These guidelines are set out in the Oslo manual (OECD , 2005) and applied in most of the member countries of OECD, in order to make the results and statistics referred to innovation issues comparable.

The Innovation Survey has been developed in nine different versions, the first in 1995 and the last in 2014. However, the heterogeneity of the different versions of the survey has the consequence that the associated databases have different structures and coding of variables, mainly due to the changes in the design of the questionnaires and the numerical domains of the variables in each period. Although it is difficult to find a variable that is available in all versions of the survey, there is greater uniformity in the presence and coding of the variables from the fifth version. Thus, the observations at firm level were consolidated from the fifth to ninth version of the survey in a single database, in order to apply the statistical analysis based on cross-sectional estimates, and then performing a comparison of results with the methodology of pseudo-panels. In Table 1, the descriptive statistics of the consolidated data is shown. 
Table 1

Statistical summary of the variables used in the analysis

\begin{tabular}{|c|c|c|c|c|c|}
\hline Variable & $\begin{array}{c}\text { Number of } \\
\text { observations }\end{array}$ & Mean & $\begin{array}{l}\text { Standard } \\
\text { deviation }\end{array}$ & $\begin{array}{c}\text { Minimal } \\
0\end{array}$ & Maximal \\
\hline Public funding & 17496 & 0.054 & 0.225 & 0 & 1 \\
\hline Expenditure on innovation equipment in t-1 & 15765 & $1.69 \mathrm{E}+05$ & 4.77E+06 & 0 & $4.39 \mathrm{E}+08$ \\
\hline Expenditure on external knowledge in t-1 & 15216 & $1.62 \mathrm{E}+04$ & $6.14 \mathrm{E}+05$ & 0 & $6.31 \mathrm{E}+07$ \\
\hline Expenditure on training for innovation in $\mathrm{t}-1$ & 15434 & 9467053.00 & $4.54 \mathrm{E}+05$ & 0 & $4.64 \mathrm{E}+07$ \\
\hline $\begin{array}{l}\text { Expenditure on introducing innovation to } \\
\text { market in } \mathrm{t}-1\end{array}$ & 15262 & $5.47 \mathrm{E}+04$ & $4.11 \mathrm{E}+06$ & 0 & $5.05 \mathrm{E}+08$ \\
\hline $\begin{array}{l}\text { Expenditure in other innovation activities } \\
\text { in } \mathrm{t}-1\end{array}$ & 19690 & $3.23 \mathrm{E}+04$ & $1.98 \mathrm{E}+06$ & 0 & $2.67 \mathrm{E}+08$ \\
\hline $\begin{array}{l}\text { Number of intellectual property rights } \\
\text { required in } \mathrm{t}-1 \text { and } \mathrm{t}\end{array}$ & 13892 & 0.509 & 19.554 & 0 & $1.93 \mathrm{E}+03$ \\
\hline Total sales in $\mathrm{t}-1$ & 21875 & $3.26 \mathrm{E}+07$ & $2.82 \mathrm{E}+08$ & 0 & $1.75 \mathrm{E}+10$ \\
\hline Number of workers in $\mathrm{t}-1$ & 21875 & $2.47 \mathrm{E}+02$ & $1.32 \mathrm{E}+03$ & 0 & $9.06 \mathrm{E}+04$ \\
\hline Export experience in $\mathrm{t}-1$ & 21875 & 0.158 & 0.365 & 0 & 1 \\
\hline Agricultural and forestry sector & 21875 & 0.060 & 0.238 & 0 & 1 \\
\hline Fishing sector & 21875 & 0.025 & 0.157 & 0 & 1 \\
\hline Mining sector & 21875 & 0.012 & 0.109 & 0 & 1 \\
\hline Manufacturing sector & 21875 & 0.291 & 0.454 & 0 & 1 \\
\hline Electricity, gas and water sector & 21875 & 0.026 & 0.160 & 0 & 1 \\
\hline Construction sector & 21875 & 0.078 & 0.268 & 0 & 1 \\
\hline Commerce sector & 21875 & 0.111 & 0.315 & 0 & 1 \\
\hline Transport sector & 21875 & 0.094 & 0.291 & 0 & 1 \\
\hline Financial services sector & 21875 & 0.041 & 0.197 & 0 & 1 \\
\hline Real estate sector & 21875 & 0.141 & 0.348 & 0 & 1 \\
\hline Social services and health sector & 21875 & 0.045 & 0.208 & 0 & 1 \\
\hline Other sectors & 21875 & 0.037 & 0.188 & 0 & 1 \\
\hline Tarapacá Region & 21875 & 0.025 & 0.157 & 0 & 1 \\
\hline Antofagasta Region & 21875 & 0.027 & 0.163 & 0 & 1 \\
\hline Atacama Region & 21875 & 0.019 & 0.135 & 0 & 1 \\
\hline Coquimbo Region & 21875 & 0.024 & 0.153 & 0 & 1 \\
\hline Valparaíso Region & 21875 & 0.047 & 0.211 & 0 & 1 \\
\hline O'Higgins region & 21875 & 0.030 & 0.169 & 0 & 1 \\
\hline Maule Region & 21875 & 0.032 & 0.175 & 0 & 1 \\
\hline Biobío Region & 21875 & 0.053 & 0.225 & 0 & 1 \\
\hline Araucanía Region & 21875 & 0.032 & 0.177 & 0 & 1 \\
\hline Los Lagos Region & 21875 & 0.040 & 0.197 & 0 & 1 \\
\hline Aysén Region & 21875 & 0.024 & 0.154 & 0 & 1 \\
\hline Magallanes Region & 21875 & 0.037 & 0.189 & 0 & 1 \\
\hline Metropolitan Region & 21875 & 0.290 & 0.454 & 0 & 1 \\
\hline Los Ríos region & 21875 & 0.019 & 0.137 & 0 & 1 \\
\hline Large firms & 21875 & 0.413 & 0.492 & 0 & 1 \\
\hline Medium firms & 21875 & 0.241 & 0.428 & 0 & 1 \\
\hline Small firms & 21875 & 0.310 & 0.462 & 0 & 1 \\
\hline Private ownership & 21875 & 0.900 & 0.301 & 0 & 1 \\
\hline Foreign ownership & 21875 & 0.055 & 0.228 & 0 & 1 \\
\hline Mixed ownership & 21875 & 0.035 & 0.185 & & 1 \\
\hline
\end{tabular}

Source: Own elaboration, based on data from the Innovation Surveys

\section{Econometric models}

Binary choice models (probit or logit) are well known and widely used in empirical applications with cross-sectional data. However, to understand the methodology of binary models with pseudo-panels, it is necessary to understand panel data. The latter are a set of 
cross-sectional data and time series data that attempt to follow the same individuals over time. Regressions based on panel data have a double subscript on the variables, where $i$ refers to individuals and $t$ indicates the time period (Baltagi, 2005).

$$
y_{i t}^{*}=x_{i t}^{\prime} \beta+\alpha_{i}+u_{i t} ; \quad t=1, \ldots, T ; i=1, \ldots, N
$$

In this case, the dependent variable $y_{i t}^{*}$ is unobservable, but the binary variable $y_{i t}$ is observed defined by $y_{i t}=1\left(y_{i t}^{*}>0\right)$ or 0 otherwise $^{6} ; x_{i t}$ is a vector of exogenous variables ${ }^{7}$ so that $E\left(u_{i t} \mid x_{i 1}, \ldots, x_{i T}, \alpha_{i}\right)=0, \beta, \beta$ is the vector of parameters to be estimated, whereas $\alpha_{i}$ is a unobservable individual effect that is potentially correlated with the explanatory variables.

With a genuine data panel, the parametric estimators typically used are the probit estimator of random effect, and the logit estimator of fixed effects. The first approach supposes that the unobservable characteristics $\alpha_{i}$ and $u_{i t}$ are normally distributed and are independent of the explanatory variables $x_{i t}$. In addition, the likelihood variable takes into account that the different observations on the same individual are dependent. However, given that $y_{i t}^{*}$ is unobservable, additional assumptions on the distribution of $\alpha_{i}$ must be made in order to estimate $\beta$. Chamberlain (1984) proposes parameterizing the conditional hope of $a_{i}$ given the exogenous variables, as a linear function of $x_{i t}$ :

$$
E\left(\alpha_{i} \mid x_{i 1}, \ldots, x_{i T}\right)=x_{i 1}^{\prime} \lambda_{1}+\cdots+x_{i T}^{\prime} \lambda_{T}
$$

Then $\alpha_{i}$ can be written as:

$$
\alpha_{i}=x_{i 1}^{\prime} \lambda_{1}+\cdots+x_{i T}^{\prime} \lambda_{T}+\theta_{i}, \quad E\left(\theta_{i} \mid x_{i 1}, \ldots, x_{i T}\right)=0
$$

By substituting (3) in (1), the form induced by the model can be obtained:

$$
y_{i t}^{*}=x_{i 1}^{\prime} \pi_{t 1}+\cdots+x_{i T}^{\prime} \pi_{t T}+\phi_{i t} ; \quad t=1, \ldots, T ; i=1, \ldots, N
$$

Where $\pi_{t s}=\lambda_{s}$ if $t \neq s, \pi_{t s}=\beta+\lambda_{t}$, and $\phi_{i t}=u_{i t}+\theta_{i}$ is the term of error, which is not correlated with $x_{i t}$. If the same individuals are observed over time (for instance, if there are authentic panel data), the reduced form of the parameters can be estimated using classic estimators for binary decision models. Thus, once the estimate of the reduced form is available, $\beta$ can be estimated by minimal distance or alternatively, a "within" estimator of groups can be obtained for $\beta$.

When there are no genuine panel data, it is possible to resort to repeated cross-sectional sections (pseudo-panels), which include data of a randomly chosen sample of individuals

\footnotetext{
${ }^{6}$ In this case, to obtain public funding for innovative activities.

${ }^{7}$ Observable characteristics in the previous year such as expenditure on equipment for innovation, expenditure on external knowledge, expenditure in training made, expenditure on introducing innovation to market, expenditure in other innovation activities, number of intellectual property requested by the firm, total sales performed, number of workers, export experience, economic sector; region, size and type of ownership.
} 
within the population in consecutive points over time. This is possible because it has been shown that many econometric models that apparently require the availability of panel data can also be estimated with repeated cross-sectional data (Collado, 1998; Verbeek \& Vella, 2005; Verbeek, 2008).

Moffitt (1993) proposes the estimation of the binary choice model with pseudo-panel data through instrumental variables. This approximation uses dummy variables of the cohorts (or other functions of the variables that defined cohorts) as instruments for explanatory variables. Specifically, each individual effect $\alpha_{i}$ is decomposed into a cohort effect $\alpha_{c}$ and the deviation of the individual $i$ of this effect. $z_{c i}=1(c=1, \ldots, C)$ is defined if the individual $i$ is member of the cohort $C$, and 0 otherwise. Thus, $a_{i}$ can be described as:

$$
\alpha_{i}=\sum_{c=1}^{C} \alpha_{c} z_{c i}+\varepsilon_{i}
$$

The above expression can be interpreted as an orthogonal projection. By defining $a=\left(a_{i}, \ldots, a_{c}\right)^{\prime}$ and $z_{i}=\left(z_{l i}, \ldots, z_{c i}\right)^{\prime}$ and substituting (5) in (1) the following is obtained:

$$
y_{i t}^{*}=x_{i t}^{\prime} \beta+z_{i}^{\prime} \alpha+\varepsilon_{i}+u_{i t} ; \quad t=1, \ldots, T
$$

If it is assumed that the instruments for $X_{i t}$ are not correlated with $\varepsilon_{i}+u_{i t}$, the estimator of the instrumental variables produces an estimator for $\beta$ and ac. In this case, an alternative is to choose cohort dummy variables in $\mathrm{Zi}$, interacting over time as instruments. In this case, linear predictors of the reduced form are derived:

$$
x_{k, i t}=z_{i}^{\prime} \delta_{k t}+w_{k, i t} ; \quad k=1, \ldots, K ; t=1, \ldots, T
$$

Where $\delta_{k t}$ is a vector of unknown parameters. The linear predictor for $x_{i t}$ is given by $\hat{x}_{i t}=\bar{x}_{c t}$, the vector of means in the cohort $\mathrm{c}$ in period $t$.

Despite the simplicity of the estimation of the binary choice model with instrumental variables, it is required that data grouped in cohorts satisfy the typical requirements of exogeneity and relevance of the instruments. This implies that the cohort dummy variables interact with time dummy variables are valid instruments for all explanatory variables of the model. Therefore, the instruments must not be correlated with the error term, but they must be sufficiently correlated with each of the explanatory variables incorporated in the model. In addition, it is required to assume that $\varepsilon_{i}+u_{i t}$ has a normal distribution.

\section{Results}

In this section, the econometric models that test the historical determinants of the firms to explain the obtaining of public funding for R\&D are presented. It should be noted that the incorporation of different explanatory variables allows proving the robustness of the identified 
relations. Therefore, diverse specifications of the empirical model are included. Model 1 only includes as explanatory variables the different types of expenses in innovative actions (expenditure on equipment for innovation, expenditure on external knowledge, expenditure in training made, expenditure on introducing innovation to market, expenditure in other innovation activities, number of intellectual property requested by the firm) performed in the previous year; model 2 also controls by total sales performed in the previous year, number of workers in the previous year and the export experience in the previous year; model 3 also controls by economic sectors; model 4 also adds a control by region of location of the firms; model 5 controls by firm size; and model 6 controls by type of ownership.

In Table 2, results obtained from the probit method are shown. These results estimate the probability of obtaining public funding through cross-sectional data of the $9^{\text {th }}$ version of the Innovation Survey ${ }^{8}$. Results show that the expenditure in training for innovation performed in the previous year has a positive and statistically significant effect at $5 \%$ in three of the six estimated models. Likewise, the expenditure in other innovative activities (design, installation of new equipment and production startup) performed in the previous year also presents positive and statistically significant impact in four models. However, the only variable that presents a significant and positive effect in all estimated specifications is the export experience in the previous year. This finding is not very encouraging for the use of public funds for innovation since Bravo-Ortega et al. (2014) demonstrate that Chilean firms that invest in R \& D are more likely to export but the reverse is not true. In addition, it can be observed that the firms belong to the construction, commerce and transport sector present a negative and statistically significant effect on the probability of obtaining public funding for R\&D. This result is somewhat discouraging because according to Alvarez et al. (2015) Chile's services sector shows a behavior in innovative inputs and outputs very similar to the manufacturing sector.

To contrast the previous results, estimates of the probit method are presented, using pseudopanel data. In Table 3 it is observed that the expenditure destined to acquire equipment, machines or software to support innovation performed in the previous year has no significant effect on the probability of obtaining public funding. However, the expenditure in training for innovation performed in the previous year has a negative effect of $1 \%$ of significance in five models. This result could be explained because the firms that have personnel prepared to perform innovation activities would not require applying for this type of funding. The other variables associated to innovative activities carried out in the previous year present robust effects both in magnitude, sign and/or statistical significance. In addition, it can be observed that the number of workers of the previous year has a positive and significant effect in four of the five models where this variable is included. This result differs from Mardones and Zapata (2018) who study the case of small and medium-sized Chilean companies, demonstrating that the probability of obtaining public financing is increased with greater expenditure on the introduction of innovations to the market in the previous year.

\footnotetext{
${ }^{8}$ The same cross-sectional analysis was also performed for each of the previous versions of this survey (from the $5^{\text {th }}$ to the $8^{\text {th }}$ version), whose results are not reported due to space issues. In this case, it was not found that the innovative activities of the previous year had a significant impact on the probability of achieving funding for R\&D. However, the export experience the only variable that shows a significant effect in all versions of the survey in all models analyzed.
} 
Table 2

Probit model results based on data from the 9th Innovation Survey

\begin{tabular}{|c|c|c|c|c|c|c|c|c|c|c|c|c|}
\hline & \multicolumn{2}{|c|}{ Model 1} & \multicolumn{2}{|c|}{ Model 2} & \multicolumn{2}{|c|}{ Model 3} & \multicolumn{2}{|c|}{ Model 4} & \multicolumn{2}{|c|}{ Model 5} & \multicolumn{2}{|c|}{ Model 6} \\
\hline & Coef. & $\begin{array}{l}\text { Standard } \\
\text { error }\end{array}$ & Coef. & $\begin{array}{l}\text { Standard } \\
\text { error }\end{array}$ & Coef. & $\begin{array}{l}\text { Standard } \\
\text { error }\end{array}$ & Coef. & $\begin{array}{c}\text { Standard } \\
\text { error }\end{array}$ & Coef. & $\begin{array}{l}\text { Standard } \\
\text { error }\end{array}$ & Coef. & $\begin{array}{l}\text { Standard } \\
\text { error }\end{array}$ \\
\hline Expenditure in equipment for innovation in $t-1$ & $5.01 \mathrm{E}-08$ & $1.17 \mathrm{E}-07$ & $1.47 \mathrm{E}-08$ & $1.31 \mathrm{E}-07$ & 2.47E-08 & $2.10 \mathrm{E}-07$ & 2.49E-08 & $2.19 \mathrm{E}-07$ & 2.18E-08 & $2.22 \mathrm{E}-07$ & $2.90 \mathrm{E}-08$ & $2.16 \mathrm{E}-07$ \\
\hline Expenditure in external knowledge in $t-1$ & 3.08E-06 & $1.77 \mathrm{E}-06$ & $2.38 \mathrm{E}-06$ & $1.88 \mathrm{E}-06$ & $2.81 \mathrm{E}-06$ & $2.24 \mathrm{E}-06$ & $2.80 \mathrm{E}-06$ & $2.24 \mathrm{E}-06$ & $2.87 \mathrm{E}-06$ & $2.27 \mathrm{E}-06$ & $2.23 \mathrm{E}-06$ & $2.29 \mathrm{E}-06$ \\
\hline Expenditure in training for innovation in $t-1$ & $2.27 \mathrm{E}-06$ & 7.81E-07 & * $1.83 \mathrm{E}-06$ & $8.03 \mathrm{E}-07 *$ & * $1.44 \mathrm{E}-06$ & $8.24 \mathrm{E}-07$ & $1.49 \mathrm{E}-06$ & $8.23 \mathrm{E}-07$ & $1.48 \mathrm{E}-06$ & $8.23 \mathrm{E}-07$ & $1.60 \mathrm{E}-06$ & $8.12 \mathrm{E}-07 *$ \\
\hline Expenditure in introduction of innovations to the market in $t-1$ & $1.04 \mathrm{E}-09$ & $1.38 \mathrm{E}-07$ & $8.26 \mathrm{E}-10$ & $1.74 \mathrm{E}-07$ & $-1.77 \mathrm{E}-08$ & $2.44 \mathrm{E}-07$ & $-1.62 \mathrm{E}-08$ & $2.50 \mathrm{E}-07$ & $-1.78 \mathrm{E}-08$ & $2.55 \mathrm{E}-07$ & $-6.58 \mathrm{E}-08$ & $4.48 \mathrm{E}-07$ \\
\hline Expenditure in other innovation activities $t-1$ & $9.47 \mathrm{E}-07$ & $2.86 \mathrm{E}-07$ & $* 8.12 \mathrm{E}-07$ & $4.20 \mathrm{E}-07$ & $2.24 \mathrm{E}-06$ & $6.52 \mathrm{E}-07$ & 2.17E-06 & $6.49 \mathrm{E}-07 * *$ & $* 2.15 \mathrm{E}-06$ & $6.49 \mathrm{E}-07 * *$ & $* 2.25 \mathrm{E}-06$ & $6.78 \mathrm{E}-07^{* *}$ \\
\hline Number of intellectual property rights required in $t-1$ and $t$ & 0.002 & 0.001 & 0.001 & 0.001 & 0.001 & 0.001 & 0.001 & 0.001 & 0.001 & 0.001 & 0.002 & 0.001 \\
\hline Total sales in $t-1$ & & & $-1.69 \mathrm{E}-10$ & $2.31 \mathrm{E}-10$ & 3.52E-10 & $1.68 \mathrm{E}-10 *$ & $* 3.60 \mathrm{E}-10$ & $1.66 \mathrm{E}-10 *$ & $* 3.54 \mathrm{E}-10$ & $1.67 \mathrm{E}-10^{*}$ & * $3.43 \mathrm{E}-10$ & $1.78 \mathrm{E}-10$ \\
\hline Number of workers in $t-1$ & & & 2.08E-05 & 2.13E-05 & 5.14E-05 & $1.78 \mathrm{E}-05 * *$ & $* 5.00 \mathrm{E}-05$ & $1.79 \mathrm{E}-05 * *$ & * 4.94E- 05 & $1.81 \mathrm{E}-05 * *$ & $* 4.86 \mathrm{E}-05$ & $1.82 \mathrm{E}-05^{* *}$ \\
\hline Export experience in $t-1$ & & & 0.580 & $0.090^{* *}$ & $* * \quad 0.558$ & $0.102 * *$ & * $\quad 0.544$ & $0.103 * *$ & $* \quad 0.542$ & $0.113^{* *}$ & $* \quad 0.548$ & $0.116^{* *}$ \\
\hline Agriculture and forestry sector & & & & & -0.089 & 0.193 & -0.094 & 0.194 & -0.090 & 0.195 & -0.079 & 0.195 \\
\hline Fishing sector & & & & & -0.505 & 0.324 & -0.535 & 0.333 & -0.523 & 0.334 & -0.532 & 0.334 \\
\hline Mining sector & & & & & -16.259 & 91.432 & -162.486 & 153.103 & -16.127 & 153.268 & -15.978 & 86.879 \\
\hline Manufacturing sector & & & & & -0.319 & 0.171 & -0.335 & 0.174 & -0.323 & 0.175 & -0.339 & 0.176 \\
\hline Electricity, gas and water sector & & & & & -0.521 & 0.371 & -0.538 & 0.372 & -0.532 & 0.378 & -0.613 & 0.392 \\
\hline Construction sector & & & & & -0.492 & $0.236 *$ & -0.515 & $0.239 *$ & -0.498 & $0.241 *$ & -0.494 & $0.241 *$ \\
\hline Commerce sector & & & & & -0.597 & $0.203 * *$ & -0.585 & $0.204 * *$ & -0.579 & $0.206 * *$ & -0.577 & $0.207^{* *}$ \\
\hline Transport sector & & & & & -0.805 & $0.262 * *$ & -0.800 & $0.262 * *$ & -0.794 & $0.263 * *$ & -0.805 & $0.266^{* *}$ \\
\hline Real estate sector & & & & & -0.247 & 0.172 & -0.256 & 0.174 & -0.245 & 0.175 & -0.247 & 0.176 \\
\hline Social services and health sector & & & & & -0.299 & 0.248 & -0.314 & 0.251 & -0.310 & 0.253 & -0.311 & 0.254 \\
\hline Other sectors & & & & & -0.194 & 0.238 & -0.206 & 0.240 & -0.195 & 0.241 & -0.193 & 0.241 \\
\hline Tarapacá Region & & & & & & & -0.274 & 0.339 & -0.275 & 0.341 & -0.258 & 0.341 \\
\hline Antofagasta Region & & & & & & & -0.606 & 0.380 & -0.610 & 0.381 & -0.597 & 0.381 \\
\hline Atacama Region & & & & & & & -0.238 & 0.376 & -0.234 & 0.376 & -0.228 & 0.377 \\
\hline Coquimbo Region & & & & & & & 0.022 & 0.298 & 0.020 & 0.299 & -0.004 & 0.302 \\
\hline Valparaíso Region & & & & & & & -0.137 & 0.292 & -0.141 & 0.293 & -0.141 & 0.294 \\
\hline O'Higgins Region & & & & & & & -0.432 & 0.363 & -0.437 & 0.363 & -0.428 & 0.364 \\
\hline Maule Region & & & & & & & 0.006 & 0.296 & 0.010 & 0.297 & 0.004 & 0.297 \\
\hline Biobío Region & & & & & & & -0.277 & 0.302 & -0.276 & 0.302 & -0.282 & 0.304 \\
\hline Araucanía Region & & & & & & & -0.338 & 0.322 & -0.341 & 0.323 & -0.337 & 0.325 \\
\hline Los Lagos Region & & & & & & & -0.395 & 0.327 & -0.400 & 0.328 & -0.402 & 0.332 \\
\hline Aysén Region & & & & & & & -0.094 & 0.274 & -0.098 & 0.275 & -0.074 & 0.276 \\
\hline Magallanes Region & & & & & & & -0.181 & 0.271 & -0.185 & 0.272 & -0.166 & 0.273 \\
\hline Metropolitan Region & & & & & & & -0.169 & 0.249 & -0.169 & 0.250 & -0.156 & 0.250 \\
\hline Los Ríos Region & & & & & & & -0.659 & 0.468 & -0.664 & 0.468 & -0.641 & 0.468 \\
\hline Large firms & & & & & & & & & 0.109 & 0.250 & 0.106 & 0.251 \\
\hline Medium firms & & & & & & & & & 0.030 & 0.254 & 0.037 & 0.255 \\
\hline Small firms & & & & & & & & & 0.133 & 0.246 & 0.135 & 0.247 \\
\hline Private ownership & & & & & & & & & & & 0.060 & 0.524 \\
\hline Foreign ownership & & & & & & & & & & & -0.297 & 0.564 \\
\hline Mixed ownership & & & & & & & & & & & 0.464 & 0.546 \\
\hline Constant & -2.057 & 0.039 & * $\quad-2.175$ & $0.046^{* *}$ & -1.858 & $0.147^{* *}$ & -1.652 & $0.283 * *$ & -1.755 & $0.364 * *$ & -1.825 & $0.642^{* *}$ \\
\hline Observations & & 562 & 20 & 5620 & & 5437 & & 5437 & & 5437 & & 5437 \\
\hline Prob $>$ chi 2 & & 0.000 & & 0.0000 & & 0.0000 & & 0.0000 & & 0.0000 & & 0.0000 \\
\hline Pseudo R2 & & 0.026 & & 0.0596 & & 0.0988 & & 0.1082 & & 0.1091 & & 0.1168 \\
\hline Log likelihood & & -561.4 & & -542.13 & & -515.94 & & -510.52 & & -510.02 & & -505.60 \\
\hline
\end{tabular}


Table 3

Pseudo-panel probit model results based on data from the 5th to the 9th Innovation Survey

\begin{tabular}{|c|c|c|c|c|c|c|c|c|c|c|c|c|c|}
\hline & \multicolumn{2}{|c|}{ Model 1} & \multicolumn{2}{|c|}{ Model 2} & \multicolumn{2}{|c|}{ Model 3} & \multicolumn{2}{|c|}{ Model 4} & \multicolumn{2}{|c|}{ Model 5} & \multicolumn{3}{|c|}{ Model 6} \\
\hline & Coef. & $\begin{array}{l}\text { Standard } \\
\text { error }\end{array}$ & Coef. & $\begin{array}{c}\begin{array}{c}\text { Standard } \\
\text { error }\end{array} \\
\end{array}$ & Coef. & $\begin{array}{c}\begin{array}{c}\text { Standard } \\
\text { error }\end{array} \\
\end{array}$ & Coef. & $\begin{array}{c}\begin{array}{c}\text { Standard } \\
\text { error }\end{array} \\
\end{array}$ & Coef. & $\begin{array}{c}\begin{array}{c}\text { Standard } \\
\text { error }\end{array} \\
\end{array}$ & Coef. & $\begin{array}{r}\begin{array}{c}\text { Standar } \\
\text { error }\end{array} \\
\end{array}$ & \\
\hline Expenditure in equipment for innovation in $t-1$ & $6.86 \mathrm{E}-09$ & $6.24 \mathrm{E}-09$ & $1.40 \mathrm{E}-08$ & $8.04 \mathrm{E}-09$ & $7.11 \mathrm{E}-09$ & $8.30 \mathrm{E}-09$ & $1.19 \mathrm{E}-08$ & $1.44 \mathrm{E}-08$ & $6.34 \mathrm{E}-09$ & $1.48 \mathrm{E}-08$ & 4.12E-08 & $1.85 \mathrm{E}-08$ & \\
\hline Expenditure in external knowledge in $t-1$ & $-1.67 \mathrm{E}-07$ & $2.04 \mathrm{E}-07$ & $1.61 \mathrm{E}-07$ & $2.03 \mathrm{E}-07$ & $4.17 \mathrm{E}-07$ & $2.14 \mathrm{E}-07$ & $1.14 \mathrm{E}-07$ & $2.34 \mathrm{E}-07$ & $-3.40 \mathrm{E}-07$ & $2.67 \mathrm{E}-07$ & $-6.40 \mathrm{E}-07$ & 2.83E-07 & * \\
\hline Expenditure in training for innovation in $t-1$ & $-1.51 \mathrm{E}-06$ & $5.13 \mathrm{E}-07^{* *}$ & $-1.16 \mathrm{E}-07$ & $7.28 \mathrm{E}-07$ & $-2.21 \mathrm{E}-06$ & $9.39 \mathrm{E}-07 *$ & $*-4.23 \mathrm{E}-06$ & 1.31E-06* & $* *-6.70 \mathrm{E}-06$ & $1.44 \mathrm{E}-06 * *$ & $*-6.38 \mathrm{E}-06$ & $1.59 \mathrm{E}-06$ & $6 * *$ \\
\hline Expenditure in introduction of innovations to the market in $t-1$ & $-4.81 \mathrm{E}-08$ & 4.36E-08 & $-1.13 \mathrm{E}-08$ & $5.74 \mathrm{E}-08$ & 7.82E-08 & $6.77 \mathrm{E}-08$ & 2.72E-07 & $1.09 \mathrm{E}-07$ & $* 5.32 \mathrm{E}-07$ & $1.30 \mathrm{E}-07 * *$ & * $5.70 \mathrm{E}-07$ & $1.34 \mathrm{E}-07$ & $7 * *$ \\
\hline Expenditure in other innovation activities $t-1$ & $1.31 \mathrm{E}-07$ & $3.59 \mathrm{E}-08^{* *}$ & $1.95 \mathrm{E}-07$ & $3.79 \mathrm{E}-08 * *$ & $* * 1.61 \mathrm{E}-07$ & $3.98 \mathrm{E}-08$ & $1.97 \mathrm{E}-07$ & $4.81 \mathrm{E}-08 *$ & ** $1.21 \mathrm{E}-07$ & $5.06 \mathrm{E}-08 *$ & $* 4.52 \mathrm{E}-08$ & $5.51 \mathrm{E}-08$ & \\
\hline Number of intellectual property rights required in $t-1$ and $t$ & 0.015 & $0.005^{* *}$ & $\quad 0.010$ & $0.005 *$ & * $\quad 0.003$ & 0.005 & 0.000 & 0.006 & 0.007 & 0.006 & 0.013 & 0.007 & \\
\hline Total sales in $t-1$ & & & $-2.02 \mathrm{E}-09$ & $5.84 \mathrm{E}-10 * *$ & $* *-1.19 \mathrm{E}-09$ & $7.98 \mathrm{E}-10$ & $-1.37 \mathrm{E}-10$ & $1.39 \mathrm{E}-09$ & $-2.70 \mathrm{E}-09$ & $1.76 \mathrm{E}-09$ & $-2.07 \mathrm{E}-09$ & $1.74 \mathrm{E}-09$ & \\
\hline Number of workers in $t-1$ & & & 1.34E-04 & $1.13 \mathrm{E}-04$ & 3.31E-04 & $1.54 \mathrm{E}-04 *$ & $* 7.69 \mathrm{E}-04$ & $2.32 \mathrm{E}-04 *$ & $* * 1.17 \mathrm{E}-03$ & $2.60 \mathrm{E}-04 * *$ & $* 1.40 \mathrm{E}-03$ & $3.01 \mathrm{E}-04$ & $4^{* *}$ \\
\hline Export experience in $t-1$ & & & 1.375 & $0.143 * *$ & 2.308 & $0.358 * *$ & $* * \quad 0.371$ & 0.612 & 1.438 & $0.667 *$ & 0.113 & 0.889 & \\
\hline Agriculture and forestry sector & & & & & 0.153 & 0.099 & 0.663 & $0.173 *$ & 1.071 & 0.226 ** & 0.940 & 0.261 & 1 ** \\
\hline Fishing sector & & & & & -0.131 & 0.189 & 0.119 & 0.266 & 0.180 & 0.284 & 0.201 & 0.308 & \\
\hline Mining sector & & & & & -2.066 & $0.741^{* *}$ & -2.801 & $0.898 *$ & -3.936 & $1.042^{* *}$ & -3.901 & 1.212 & $2^{* *}$ \\
\hline Manufacturing sector & & & & & -0.177 & $0.084 *$ & 0.318 & 0.146 & 0.537 & $0.200^{* *}$ & 0.871 & 0.243 & $3 * *$ \\
\hline Electricity. gas and water sector & & & & & 0.624 & $0.175^{* *}$ & 0.377 & 0.239 & -0.374 & 0.313 & 0.390 & 0.473 & \\
\hline Construction sector & & & & & 0.083 & 0.114 & -0.236 & 0.173 & -0.317 & 0.180 & -0.694 & 0.217 & $7 * *$ \\
\hline Commerce sector & & & & & -0.298 & $0.084^{* *}$ & -0.228 & 0.121 & -0.371 & $0.146^{*}$ & -0.487 & 0.167 & $7 * *$ \\
\hline Transport sector & & & & & -0.157 & 0.094 & -0.053 & 0.117 & 0.389 & $0.155^{*}$ & 0.285 & 0.178 & \\
\hline Financial services sector & & & & & -0.277 & 0.209 & -1.103 & $0.286 *$ & -1.605 & $0.451^{* *}$ & -2.039 & 0.459 & $9 * *$ \\
\hline Real estate sector & & & & & 0.189 & $0.072 * *$ & 0.299 & 0.117 & 0.723 & $0.141^{* *}$ & 0.639 & 0.185 & $5 * *$ \\
\hline Social services and health sector & & & & & 0.276 & $0.138 *$ & 0.056 & 0.206 & 0.766 & $0.236 * *$ & 1.105 & 0.295 & $5 * *$ \\
\hline Other sectors & & & & & 0.736 & $0.177 * *$ & 0.635 & $0.232 *$ & 0.984 & 0.272 ** & 0.748 & 0.303 & $3 *$ \\
\hline Tarapacá Region & & & & & & & 6.502 & 2.555 & 1.194 & 2.950 & 3.125 & 3.074 & \\
\hline Antofagasta Region & & & & & & & 2.581 & 2.568 & 3.721 & 2.650 & 2.574 & 2.822 & \\
\hline Atacama Region & & & & & & & -3.084 & 2.338 & -4.647 & 2.657 & 1.608 & 3.324 & \\
\hline Coquimbo Region & & & & & & & 3.619 & 4.121 & -1.102 & 4.448 & -15.803 & 6.113 & * \\
\hline Valparaiso Region & & & & & & & -7.960 & $2.063 *$ & -8.246 & $2.414^{* *}$ & -6.056 & 2.674 & * \\
\hline O'Higgins Region & & & & & & & 1.633 & 2.502 & 2.759 & 2.579 & 8.563 & 3.106 & $6 * *$ \\
\hline Maule Region & & & & & & & -6.094 & 2.450 & -5.261 & $2.497^{*}$ & -5.257 & 2.747 & \\
\hline Biobío Region & & & & & & & 8.282 & $1.494 *$ & 4.802 & $1.694^{* *}$ & 6.385 & 1.965 & $5 * *$ \\
\hline Araucanía Region & & & & & & & 1.304 & 2.143 & 0.177 & 2.362 & -4.927 & 2.792 & \\
\hline Los Lagos Region & & & & & & & -2.464 & 1.110 & -2.454 & 1.140 & -1.490 & 1.238 & \\
\hline Aysén Region & & & & & & & -3.149 & 2.854 & -5.662 & 3.596 & -5.719 & 3.553 & \\
\hline Magallanes Region & & & & & & & -3.849 & 2.625 & -1.130 & 3.100 & 0.082 & 3.119 & \\
\hline Metropolitan Region & & & & & & & -1.417 & $0.266 *$ & -0.626 & 0.330 & -0.626 & 0.373 & \\
\hline Los Ríos Region & & & & & & & 7.026 & $2.396 *$ & 8.406 & $2.860 * *$ & 7.262 & 2.901 & $1 *$ \\
\hline Large firms & & & & & & & & & -4.851 & $2.177 *$ & -7.849 & 2.301 & $1 * *$ \\
\hline Medium firms & & & & & & & & & -7.342 & $1.962 * *$ & -9.969 & 2.170 & 0 ** \\
\hline Small firms & & & & & & & & & -8.141 & $2.516^{* *}$ & $* \quad-11.532$ & 2.694 & $4 * *$ \\
\hline Private ownership & & & & & & & & & & & 9.164 & 4.410 & $0 *$ \\
\hline Foreign ownership & & & & & & & & & & & 13.498 & 5.582 & $2 *$ \\
\hline Mixed ownership & & & & & & & & & & & -0.590 & 3.877 & \\
\hline Constant & -1.662 & $0.017^{* *}$ & -1.873 & $0.034^{* *}$ & -2.050 & $0.069 * *$ & -1.612 & $0.098 *$ & 4.497 & $2.052 *$ & -1.490 & 4.753 & \\
\hline Observations & & 17496 & & 17496 & & 17496 & & 1749 & & 17496 & & & 7496 \\
\hline Prob $>$ chi 2 & & 0.0000 & & 0.0000 & & 0.0000 & & 0.000 & & 0.0000 & & 0.00 & 0000 \\
\hline Pseudo R2 & & 0.0100 & & 0.0233 & & 0.0322 & & 0.067 & & 0.0716 & & 0.07 & 0733 \\
\hline Log likelihood & & -3620.49 & & -3571.61 & & -3539.11 & & -3411.4 & & -3395.23 & & -3388 & \\
\hline
\end{tabular}

Source: Own elaboration. Note: $\left({ }^{*}\right)$ significant at $5 \%$ and $(* *)$ significant at $1 \%$. 
Regarding other variables that characterize the firms, it is concluded that those firms that belong to the real estate sector and other services are more likely to obtain public funding for innovation, whereas those firms that belong to mining and financial sectors show less probability of obtaining support. This could be explained by the high profitability of these last sectors that could limit their propensity to apply for this type of funds. At regional level, Los Lagos and Biobío Regions highlight by having greater probabilities of obtaining funding with positive and statistically significant coefficients. In the case of the latter region, this could be explained by the presence of the INNOVA Biobío program, which exclusively supports innovations of firms based in this region. The opposite situation occurs with the firms based on the Valparaiso Region, which present lower probability of obtaining public funding. In addition, it is observed that foreign firms have more probability than national firms and these, in turn, are more likely than public or mixed firms. Finally, it is striking to note that the smaller the firm size is also less likely to obtain funding, because it was expected that small and medium firms had more probabilities to obtain support, given the objectives declared in the existing public programs.

Results obtained with the probit method with cross-sectional and pseudo-panel data have a great contrast with the findings in the international literature. According to the summary of Table 4, it is expected that firms with more innovative activities in the previous period were more likely to obtain public funding (Antonelli \& Crespi, 2013; Dush et al., 2011). On the other hand, with the pseudo-panel methodology it is observed that in the case of Chile the firms that spend more in training their workers in $R \& D$ in the previous year reduce their probability of obtaining this type of funding. It is also expected that the size of the firms and the number of workers of the previous year had an effect on the probability of obtaining funding (Duguet, 2003; Antonelli \& Crespi, 2013; Takalo et al., 2008; Almus \& Carnitzki, 2003). In the Chilean case, these positive effects were detected only with the pseudo-panel method. In addition, this result is contradictory because most of the public programs implemented in the country indicate in their bases that they are oriented mainly to the promotion of SMEs, such as the INNOVA CHILE Program. The export experience has been a relevant variable in some studies (Afcha, 2012; Huergo et al., 2016), because the firms that export their products face greater competition, which force them to be more competitive and innovative. Thus, state agencies could reward this feature by assigning their funds to projects with potential international success. In some international studies it is observed that geographical location can play a significant role in the allocation of funds (Hussinger, 2008; Dush et al., 2011), though it is not detected in each region included in this study. Other studies mention that the firms that belong to medium and/ or high technology sectors are, more likely to obtain public funds. However, this classification of sectors can not be captured from the available data, but it is observed that belonging to certain economic sectors influence that probability. Nevertheless, the identified sectors change according to the type of data available (cross-sectional or pseudo-panel). Finally, it can be mentioned that most studies affirm that a foreign-owned firm is less likely to obtain public funding (Busom, 2000; Almus \& Carnitzki, 2003; Hussinger, 2008), but when pseudo-panel data are analyzed it is determined that this characteristic has a positive effect in Chile. This can be explained because foreign capital firms can be perceived as more innovative by the state agency that allocates the funding. 
Table 4

Summary of factors that explain the public funding in R\&D

\begin{tabular}{ll}
\hline Authors & Significant variables \\
\hline Antonelli \& Crespi (2013) & $\begin{array}{l}\text { If the firm received a subsidy for R\&D in t-1 (+); age (+); size (-); number of } \\
\text { workers in R\&D in t-1 (+) }\end{array}$
\end{tabular}

Duguet (2003)

Size (+); Intensity of the expenditure in R\&D (+); debt to sales ratio (+); if the firm received subsidy in the past $(+)$; business line $(+$ or -$)$

Afcha (2012)

Cooperation with firms and institutions $(+)$; recruitment of recently graduated workers $(+)$; expenditure in R\&D in t-1 (+); medium and high technology sector $(+)$; number of workers $(+)$; exports $(+)$

Dush et al. (2011)

Expenditure in R\&D in t-1 (+); location (-); application for R\&D subsidies in previous periods $(+)$

Hussinger (2008)

Intensity of subsidy in R\&D in t-1 (+); number of workers $(+)$; number of financed projects in t-1 (-); R\&D Department $(+)$; stock of patents $(+)$; capital of the firm (+); exports (+); foreign ownership (-); geographical location (+ or -)

Almus \& Carnitzki (2003)

Busom (2000)

Takalo et al. (2008)

Gongora-Bianchi et al. (2009)

Huego et al. (2016)
Industrial sector (+ or -); number of workers (+); foreign property (-); market concentration (-); R\&D Department (+)

Number of workers (-); age (+); number of patents (+); state property (+); foreign property (-)

Project risk (-); technical challenge (+); number of employees (+); SME (+)

Exports (+); high technology (+); type of strategy (+ or -)

Expenditure in R\&D per employee in $\mathrm{t}-1(+)$; technological cooperation in $\mathrm{t}-1$ $(+)$; technological sector $(+$ or -$)$; number of workers $(+)$; exports in $t-1(+)$; experience with funding agencies in previous years $(+)$; financial difficulties for innovation $(+)$

Source: own elaboration from cited studies.

\section{Conclusions}

It can be concluded that using pseudo-panel information allows identifying factors that affect the probability of obtaining public support, which are not identified when only cross-sectional information is used. Moreover, changes in sign, magnitude and/or statistical significance can be observed for some explanatory variables.

Thus, this research provides useful information for the firms that intend to apply for public funding for innovation, because it allows them to decide what activities will be performed in order to increase the probability of obtaining support. In addition, by comparing the results of this study with the international literature it is observed that in general, the factors that explain the allocation of public funds for innovation in other countries are not replicated in the case of Chile. This allows concluding that the allocation criteria for allocating these funds should be changed and made explicit in order to allocate resources to national small or medium firms that typically face greater financial constraints for the performance of innovative projects and/ or with high social returns. 
Specifically, when using pseudo-panels there is evidence that the firms that invest in training their employees in innovative activities in the previous period are less likely to obtain public support for innovation. Perhaps, this can be attributed to the fact that this type of firms requires no public funding to develop their innovative activities and therefore, there is no application for this type of instruments. Other types of expenditures in innovative activities carried out in the previous year that was included in the analysis present no robust and significant effects. Thus, these results partially contradict the initial hypothesis that assumed that the state agency could construct a strategy of "picking the winners", i.e. that the probability of obtaining funding could be greater in firms with patents, personnel and previous experience in R\&D. This could be associated with a reputation effect that is not identified from the data analyzed for the Chilean case. In addition, this result could be explained by the fact that according the $9^{\text {th }}$ version of the Innovation Survey only $23.9 \%$ of the firms assign a high importance to the lack of financing to develop innovative activities. On the other hand, only $31.9 \%$ of the firms assign a high importance to the lack of own funds to develop innovative activities, which would imply that the firms that have an innovative trajectory not necessarily are applying to public funding programs for R\&D.

Another striking result of this study is that the smaller firms are less likely to obtain these funds, which is in contrast to the objectives declared by many of the public funding programs existing in Chile. However, this result is consistent with various previous studies that determine that the probability of obtaining public funding is greater in the case of larger firms (Duguet, 2003; Corchuelo \& Martínez-Ros, 2010; Herrera \& Sánchez, 2012). This can be explained by the fact that larger firms have economies of scale and scope associated with R\&D activities, as well as better organizational structure and suffer less from market imperfections. As most programs and instruments for R\&D in Chile affirm that they seek to enhance SMEs ${ }^{9}$, the implication of the policy is clear. Programs must be reformulated so that they are effectively oriented to SMEs, as well as improving the dissemination of the different existing instruments and motivate the firms to use them, since according to international studies; subsidies have a positive effect in the innovative process of the firms.

Additionally, it is determined from pseudo-panel data that foreign-owned firms present positive and statistically significant effects on the probability of obtaining funding. This result contrasts with international studies that find that in general, state agencies tend to privilege to national firms in order to allocate public funding for R\&D. Thus, it is concluded that the promotion of SMEs with national capitals should be made explicit in the allocation of the different programs of public funding, since this type of firms are those that present greater restrictions to credit and face greater risks to develop innovative activities.

\footnotetext{
${ }^{9}$ According to data available from the 5th to the 8th version of the Innovation Survey, $7.1 \%$ of the large firms have obtained this type of funding, whereas in the case of SMEs, only $4.2 \%$ has achieved it.
} 


\section{References}

Afcha S. (2012). Analyzing the interaction between R\&D subsidies and firm's innovation strategy. Journal of Technology Management \& Innovation, 7, 57-70. https://doi.org/10.4067/s0718-27242012000300006

Almus, M. \& Czarnitzki, D. (2003). The Effects of Public R\&D Subsidies on Firms' Innovation Activities, Journal of Business \& Economic Statistics, 21(2), 226-236. https://doi.org/10.1198/073500103288618918

Álvarez, R., Bravo-Ortega, C., \& Navarro, L. (2011). Innovación, investigación y desarrollo, y productividad en Chile. Revista CEPAL, 104, 141-166.

Álvarez, R., Bravo-Ortega, C., \& Zahler, A. (2015). Innovation and Productivity in Services: Evidence from Chile. Emerging Markets Finance and Trade, 51(3), 593-611, https://doi.org/10.1080/1540496x.2015.1026696

Antonelli, C. \& Crespi, F. (2013). The "Matthew effect" in R\&D public subsidies: The Italian evidence. Technological Forecasting and Social Change, 80(8), 1523-1534. https://doi.org/10.1016/j.techfore.2013.03.008

Baltagi B. (2005). Econometric Analysis of Panel Data. John Wiley \& Sons Ltd, third edition.

Bravo-Ortega, C., Benavente, J.M. \& González A. (2014). Innovation, Exports, and Productivity: Learning and Self-Selection in Chile. Emerging Markets Finance and Trade, 50:sup1, 68-95, https://doi.org/10.2753/ree1540496x5001s 105

Benavente J. (2005). Investigación y desarrollo, innovación y productividad: un análisis econométrico a nivel de la firma. Estudios de Economía, 32, 39-67.

Benavente, J.M. (2006). The Role of Research and Innovation in Promoting Productivity in Chile. Economics of Innovation and New Technology 15(4-5), 301-315. https://doi.org/10.1080/10438590500512794

Blanes, V., \& Busom, I. (2004). Who participates in R\&D subsidy programs?: The case of Spanish manufacturing firms. Research Policy, 33, 1459-1476. https://doi.org/10.1016/j.respol.2004.07.006

Boeing, P. (2016). The allocation and effectiveness of China's R\&D subsidies - Evidence from listed firms. Research Policy, 45(9), 1774-1789. https://doi.org/10.1016/j.respol.2016.05.007

Bozeman, B. \& Link, A. (1984). Tax incentives for R\&D: a critical evaluation. Research Policy, 13(1), 21-31. https:// doi.org/10.1016/0048-7333(84)90004-0

Bronzini R., Piselli P. (2016). The impact of R\&D subsidies on firm innovation. Research Policy, 45, 442-457. https:// doi.org/10.1016/j.respol.2015.10.008

Busom, I. (2000). An Empirical Evaluation of the effects of R\&D subsidies. Economics of Innovation and New Technology, 9(2), 111-148. https://doi.org/10.1080/10438590000000006

Cantner, U. \& Kösters, S. (2012). Picking the winner? Empirical evidence on the targeting of R\&D subsidies to startups. Small Business Economics, 39(4), 921-936. https://doi.org/10.1007/s11187-011-9340-9

Cappelen A., Raknerud A., Rybalka M. (2012). The effects of R\&D tax credits on patenting and innovations. Research Policy, 41, 334-345. https://doi.org/10.1016/j.respol.2011.10.001

Cerulli, G. (2010). Modelling and measuring the effect of public subsidies on business R\&D: A critical review of the econometric literature. Economic Record, 86, 421-449. https://doi.org/10.1111/j.1475-4932.2009.00615.x

Cerulli, G., \& Potì, B. (2012). The differential impact of privately and publicly funded R\&D on R\&D investment and innovation: the Italian case, Prometheus, 30(1), 113-149. https://doi.org/10.1080/08109028.2012.671288

Chamberlain, G. (1984), Panel Data, in: Z. Griliches and M.D. Intrilligator, eds., Handbook of Econometrics, Volume 2, Elsevier Science, North-Holland. https://doi.org/10.1016/s1573-4412(84)02014-6

Clausen T. (2009). Do subsidies have positive impacts on R\&D and innovation activities at the firm level? Structural Change and Economic Dynamics, 20, 239-253. https://doi.org/10.1016/j.strueco.2009.09.004

Collado M. (1998). Estimating binary choice models from cohort data. Investigaciones Económicas, XXII, $259-279$.

Colombo M., Grilli L., Murtinu S. (2011). R\&D subsidies and the performance of high-tech start-ups. Economics Letters, 112, 97-99. https://doi.org/10.1016/j.econlet.2011.03.007

Corchuelo, B., \& Martínez-Ros, E. (2010). Who Benefits from R\&D Tax Policy? Cuadernos de Economía y Dirección de la Empresa, 13, 145-170. https://doi.org/10.1016/s1138-5758(10)70027-x

Crespi, G., \& Zuniga, P. (2012). Innovation and Productivity: Evidence from Six Latin American Countries. World Development, 40(2), 273-290. https://doi.org/10.1016/j.worlddev.2011.07.010 
Duguet, E. (2003). Are R\&D Subsidies a Substitute or a Complement to Privately Funded R\&D? Evidence from France using Propensity Score Methods for Non-Experimental Data. University of Paris I Cahier de la MSE EUREQua Working Paper No. 2003.75. Available in: http://econwpa.repec.org/eps/pe/papers/0411/0411007.pdf

Dush N., García J., Montolio D. (2011). The link between public support and private effort: What is the Optimal Subsidy? Working Papers No 2011-09. Available in: http://www.xreap.cat/RePEc/xrp/pdf/XREAP2011-09.pdf

Góngora-Biachi, G., Madrid Guijarro, A., \& García Pérez de Lema, D. (2009). Ayudas públicas a la innovación: una evidencia empírica de la PYME industrial del sureste mexicano. Innovar, 19, 65-82.

Herrera, L., \& Sanchez González, G. (2012). Firm size and innovation policy. International Small Business Journal, 31(2), 137-155. https://doi.org/10.1177/0266242611405553

Huergo E., Trenado M., Ubierna A. (2016). The impact of public support on firm propensity to engage in R\&D: Spanish experience. Technological Forecasting \& Social Change, 113(B), 206-219. https://doi.org/10.1016/j. techfore.2015.05.011

Hussinger, K. (2008). R\&D and subsidies at the firm level: an application of parametric and semi-parametric two-step selection models. Journal of Applied Econometrics, 23, 729-747. https://doi.org/10.1002/jae.1016

Mardones, C. \& Zapata, A. (2018). Factors explaining firms' receipt of public funding for innovation: the case of Chilean small and medium-sized enterprises. Journal of Technology Management \& Innovation, 13, 2, 12-22. https:// doi.org/10.4067/s0718-27242018000200012

Moffitt R. (1993). Identification and estimation of dynamic models with a time series of repeated cross-sections. Journal of Econometrics, 59, 99-123. https://doi.org/10.1016/0304-4076(93)90041-3

Mohnen, P. \& Röller, L. (2005). Complementarities in Innovation Policy. European Economic Review, 49(6), 14311450. https://doi.org/10.1016/j.euroecorev.2003.12.003

OCDE (2005). Manual de Oslo: Guía para la recolección e interpretación de datos sobre innovación. Available in: http://www.itq.edu.mx/convocatorias/manualdeoslo.pdf

Navarro, J., Llisterri, J, \& Zuñiga, P. (2010). The Importance of Ideas: Innovation and Productivity in Latin America. In: C. Pagés, editor. The Age of Productivity: Transforming Economies From the Bottom Up. Development in the Americas Report. Washington, DC, United States: Inter-American Development Bank/Palgrave-McMillan. https://doi.org/10.1057/9780230107618_10

Takalo, T., Tanayama, T., \& Toivanen, T. (2008). Evaluating innovation policy: a structural treatment effect model of R\&D subsidies, Bank of Finland Research Discussion Papers 7, 2008. Available in: https://helda.helsinki.fi/bof/ bitstream/handle/123456789/7492/157657.pdf?sequence=1

Verbeek M., \& Vella F. (2005). Estimating dynamic models from repeated cross-sections. Journal of Econometrics, 127, 83-102. https://doi.org/10.1016/j.jeconom.2004.06.004

Verbeek M. (2008). Pseudo-Panels and repeated Cross-Sections. In The Econometrics of Panel Data. Springer, third edition, pp. 369-383. https://doi.org/10.1007/978-3-540-75892-1_11 